\title{
CORPORATE AFFILIATES
}

As The Importance of The Materials Community Grows, So Grows The Roster Of Institutions Supporting The MRS

The Corporate Affiliates Program of the Materials Research Society involves government, industrial, and other institutions as allies in an MRS-sponsored effort to improve communication among materials professionals for the advancement of research and applications.

\section{Support Grows}

Chairman of the Society's Corporate Participation Committee, C.W. Draper, AT\&T Technologies, The Engineering Research Center, notes: "With the prominence of the Materials Research Society in the materials

Some 54 Companies and Laboratories

- The Largest Number in our History-

Support the Society's Range of Services

community, support for our programs is growing rapidly. Our meetings cover research and applications of direct interest to an expanding number of industrial and governmental laboratories, as well as universities, and our membership is a particularly appropriate body of scientists, engineers, and technologists with which they wish to relate."

Draper notes that MRS Corporate Affiliates receive a number of benefits, including literature displays without charge at MRS meetings, announcements in the BULLETIN, a complimentary subscription to the MRS-affiliated letters journal, Materials Letters and various forms of recognition. "We also benefit from suggestions by Corporate Affiliates about topics for possible future symposia," Draper notes.

\section{Roster of Affiliates}

The current roster of the Materials Research Society's Corporate Affiliates includes the following:

Air Products and Chemicals

Allied Corporation

Aluminum Company of America

Atlantic Cement Company

AT\&T Technologies (The Engineering Research Center)

Branson, IPC

Brimrose Corporation of America

Chevron
Coherent

E.1. DuPont de Nemours \& Company

Eastman Kodak Company

Eaton Corporation

EG\&G ORTEC

Elborg Technology Company

Elsevier North-Holland

Exxon Research and Engineering Company

General Electric Company

General Ionex Corporation

General Motors Research Laboratories

GTE Laboratories

Harshaw/Filtrol

Helionetics

Hitachi Microscopes

International Business Machines Corporation Jeol USA

Lam Research

Lambda Physik

Lawrence Livermore National Laboratory

Lumonics

Martin Marietta Laboratories

Microscience, Inc.

Monsanto

Perkin-Elmer

Philips Electronic Instruments, Inc.

Portland Cement Association

Quantronix Corporation

Questek, Inc.

Sandia National Laboratories

Schlumberger-Doll Research

Shell Development Company

Spectra Physics

Spire Corporation

Standard Oil Company of Indiana

TRW

Tegal Corporation

Union Carbide Corporation

United Technologies Research Center UOP

Varian/Extrion

W.R. Grace \& Company

Westinghouse Electric Corporation

Xerox Corporation

XMR

Zymet 